Małgorzata Jakobsze

Uniwersytet Boloński

\title{
Podręcznik tradycyjny czy e-learning? Wybór podręcznika kursowego na lektorat akademicki z języka polskiego jako obcego (na przykładzie polonistyki włoskiej)
}

Każdego roku na rynku wydawniczym niemal lawinowo przybywa publikacji do nauki i nauczania języka polskiego jako obcego, mnożą się serie wydawnicze o charakterze metodycznym przeznaczone dla nauczycieli, pojawia się coraz więcej publikacji specjalistycznych, co niezmiernie cieszy zarówno lektorów, jak i studentów. Różnorodność i bogactwo materiałów dydaktycznych skłania jednak też do refleksji, by wybrać pozycję, która byłaby najbardziej adekwatna do profilu kursu i - a raczej przede wszystkim - spełniałaby oczekiwania uczniów oraz efektywnie przeprowadziła ich przez tajniki i zawiłości polszczyzny. Wybór ten nie jest łatwy i powinien zostać poprzedzony wnikliwą analizą potrzeb i możliwości, szczególnie jeśli mowa o lektoratach prowadzonych poza granicami kraju, gdzie dostęp do podręczników wydawanych w Polsce jest utrudniony (trzeba je zamawiać), studenci w większości należą do jednorodnej grupy etnicznej (rodziny językowej), a nauczanie odbywa się w warunkach niemożliwych do ,zanurzenia się" w języku docelowym. Są to zasadnicze i wspólne cechy edukacji na lektoratach uniwersyteckich poza granicami Polski, odróżniające je od kursów prowadzonych w krajowych szkołach językowych i przyuczelnianych studiach bądź centrach nauczania języka polskiego jako obcego, gdzie lwią część stanowią grupy mieszane pod względem etnicznym. Do tych ogólnych i oczywistych cech nauczania za granicą należy jeszcze dodać specyficzne uwarunkowania (społeczne, administracyjne, budżetowe, lokalowe itp.) odmienne dla każdej społeczności akademickiej. Zatem ze względu na obszerność tematu skoncentruję się w swoich rozważaniach wyłącznie na przykładzie studiów polonistycznych w Italii.

Terminem ,polonistyka włoska” obejmuję w tym artykule w istocie konglomerat środowiskowy, składający się z kilkunastu katedr polonistyki, należących 
w większości do tzw. małych specjalizacji, czyli jednostek administrujących zajęcia $\mathrm{z}$ literatury i języka polskiego w ramach studiów slawistycznych lub językoznawczych. Obecnie zajęcia prowadzone są w 14 ośrodkach akademickich na terenie całych Włoch: w Bari, Bolonii, Florencji, Genui, Lecce, Mediolanie, Neapolu, Padwie, Pizie, Rzymie (uniwersytety „La Sapienza” i „,Tor Vergata”), Turynie, Udine i w Wenecji [zob. Lektoraty języka polskiego... 2016]. Wydziały, na których oferowana jest edukacja polonistyczna, można podzielić na trzy grupy ze względu na stopień sprofilowania filologicznego każdej z jednostek: Wydział Literatury i Filozofii, Wydział Literatur i Języków Obcych oraz Wydział Humanistyczny [Marzec 2009: 25]. Uściślić należy, iż terminu ,polonistyka” używam w niniejszej pracy zwyczajowo i nie może być on odnoszony i porównywany do kształcenia polonistycznego na studiach filologicznych w Polsce. Co prawda, istnieją alternatywne nomenklatury dla terminu ,polonistyka zagraniczna” (np. „studia polskie” lub ,studium języka i kultury polskiej”), co stało się nawet przedmiotem dyskusji językoznawczej [Marzec 2009: 43], jednak w moim przekonaniu nie oddają one specyfiki prowadzonych za granicą zajęć. Pierwszy termin wydaje się zbyt ogólnikowy w porównaniu z rzeczywistym programem studiów, podczas gdy drugie określenie przywołuje na myśl działające przy polskich uniwersytetach centra języka i kultury dla cudzoziemców, osadzone w zupełnie innej rzeczywistości niż studia akademickie poza granicami kraju.

Większość uniwersytetów włoskich oprócz zajęć historycznoliterackich w swojej ofercie dydaktycznej proponuje także blok zajęć językoznawczych, wśród których rozróżnia się praktyczną naukę języka polskiego (tzw. lektorat) oraz często kurs z teorii gramatyki opisowej w formie wykładów lub konwersatorium. Mając na uwadze to istotne rozróżnienie między dwoma dopełniającymi się kursami języka, skoncentruję się na wyborze podręcznika do pierwszego rodzaju zajęć - lektoratu akademickiego. Dobór ten zależny jest od wielu czynników, wśród których prym wiedzie najważniejszy, czyli adresat takiego podręcznika kursowego. Zważywszy na obszar badań, ograniczony do studiów wyższych polonistycznych, nieco łatwiej jest nakreślić profil studenta oraz przewidzieć jego oczekiwania względem kursu w odróżnieniu od grupy mieszanej bez ugruntowanej wiedzy filologicznej. Dzięki badaniom ankietowym Urszuli Marzec przeprowadzonym niemal we wszystkich ośrodkach włoskiej polonistyki w 2007 roku możemy przyjąć (pamiętając o marginesie błędu uwzględniającym dziewięcioletnią już perspektywę badań), że motywacją do podjęcia studiów polonistycznych studenta włoskojęzycznego są zainteresowania językami słowiańskimi oraz kulturą Polski, często wykształcone już po pierwszym kontakcie z naszym krajem (poprzez podróże, kursy językowe, 
pobyty stypendialne lub polskich znajomych). Istotna jest też chęć związania z polszczyzną przyszłej pracy zawodowej bądź naukowej - najczęściej w charakterze thumacza, pracownika włoskich przedsiębiorstw utrzymujących kontakty biznesowe z Polską, lektora języka włoskiego lub pracownika sektora turystycznego [Marzec 2009: 88].

$\mathrm{Z}$ dużym prawdopodobieństwem można założyć, że nasz student wybrał język polski jako jeden z dwóch języków wiodących w swoim programie studiów i równocześnie uczy się języka angielskiego lub rosyjskiego oraz chętnie uczestniczy we wszystkich inicjatywach pozauniwersyteckich [Marzec 2009: 91]. Nasz statystyczny student wydaje się studentem idealnym, a praca z nim to źródło czystej satysfakcji. I choć faktycznie lektorzy uczący we Włoszech często podkreślają satysfakcję z wykonywanej pracy, to jednak zapał ten znacznie studzą napotykane trudności, szczególnie natury administracyjnej, które - niestety - pozostawiają negatywne ślady na jakości pracy dydaktycznej. Wśród przykładowych problemów możemy przytoczyć za Teresą Wilkoń [2007: 260]: nieobligatoryjność zajęć, z czym wiąże się wybiórcza frekwencja, aż sześć terminów egzaminacyjnych, możliwość niezaakceptowania oceny z egzaminu ustnego przez studenta, krótki rok akademicki ze względu na trwające tygodniami sesje i inne przerwy w nauce, biurokratyzm, brak perspektyw naukowych i etatowych, ograniczenia kadrowe itp. Jest to kontekst sytuacyjny, który nie tylko pejoratywnie wpływa na jakość pracy, ale także - pośrednio - na pewne wybory formalne, np. dotyczące podręcznika kursowego. Skoro bowiem istnieje teoretyczna możliwość podejścia do egzaminu bez regularnego (lub zupełnego) uczestnictwa w zajęciach, to czy i podręcznik nie powinien mieć charakteru autodydaktycznego?

Kolejnym krokiem po refleksji nad sylwetką studenta jest określenie języka medium kursu (a zatem i języka podręcznika), co często predestynuje wybór konkretnej metody pracy ze studentem. Metody bezpośrednie (w szczególności metoda naturalna) pozwalają na operowanie tylko językiem docelowym podczas lekcji - w tym wypadku językiem polskim. Metody pośrednie wykorzystują język wyjściowy (włoski) jako niezbędny w procesie kształcenia, kładąc szczególny nacisk na nauczanie treści gramatycznych, które są w tym języku najczęściej wykładane. Metody pośredniczące stanowią natomiast pewien kompromis - z języka medium korzysta się tylko w charakterze języka pomocniczego i służącego do objaśniania struktur gramatycznych, czego przykładem może być metoda kognitywistyczna [Seretny 2006: 132]. Pozostając tylko przy tak ogólnym rozróżnieniu metod nauczania, konstytuowanych przez rolę języka medium, przechodzimy do profilu lektora, gdyż wybór języka medium często determinowany jest jego kompetencją językową. Jeśli włada on bardzo 
dobrze językiem obcym - ojczystym dla grupy studentów - ma całe spektrum możliwości metodycznych. Nieznajomość języka wyjściowego studentów nierzadko zmusza natomiast lektora do skupienia się na metodach wchodzących w krąg metodyki bezpośredniej, ewentualnie pośredniczącej. Innym rozwiązaniem (stosowanym najchętniej w przyuniwersyteckich szkołach języka polskiego i dla grup różnorodnych etnicznie) jest wprowadzenie trzeciego języka medium - przeważnie języka angielskiego. Rozwiązanie to jest jednak rzadko wykorzystywane poza granicami kraju.

Po swoistej procedurze określenia profilu studenta, przeanalizowaniu kontekstu sytuacji edukacyjnej, wyborze metody nauczania ${ }^{1}$ oraz określeniu języka medium można przejść do meritum dyskursu, czyli wyboru właściwego podręcznika kursowego, tj. pozycji przewodniej wykorzystywanej podczas zajęć. W praktyce okazuje się jednak, że wskazanie jednego tytułu jest niemal niemożliwe, a włoskie sylabusy zawierają przynajmniej kilkanaście pozycji i sytuacja ta nie zmieniła się od czasów wspomnianych wcześniej badań ankietowych:

Lektorzy zapytani o podręczniki kursowe bardzo rzadko wymieniali tytuł tylko jednej książki, z której korzystają w czasie zajęć, najczęściej wpisywali w kwestionariuszu zestawy podręczników, dlatego w większości przypadków nie można jednoznacznie stwierdzić, w jakie podręczniki zaopatrzeni są studenci i czy istnieje jakiś jeden podręcznik wiodący dla grup na poszczególnych poziomach zaawansowania. [Marzec 2009: 60]

Te trudne realia wyboru podręcznika dodatkowo komplikuje fakt, iż większość dostępnych na rynku publikacji ma charakter uniwersalny, czyli implikuje niezróżnicowanego etnicznie odbiorcę i operuje tylko językiem polskim. Mowa tu o podręcznikach ogólnych, przeznaczonych przede wszystkim do pracy z grupą różnorodną pod względem języka ojczystego [Lipińska, Seretny 2005: 309]. Publikacje te cechuje m.in. schematyczny i uproszczony sposób prezentowania treści gramatycznych, unikanie trudnej terminologii językoznawczej oraz nachylenie pod kątem kształtowania wszystkich sprawności językowych zgodnie ze standardami egzaminów certyfikowanych z języka polskiego jako obcego. Do takich pozycji należą m.in. wydany w Katowicach w 1999 roku podręcznik Dzień dobry... autorek Aleksandry Janowskiej

1 Oczywiście wachlarz możliwości metodycznych jest znacznie szerszy. W artykule zastosowano tylko stosunkowo ogólnikowy podział na podstawie kryterium roli języka ojczystego studentów i ich świadomości w procesie nauczania. 
i Magdaleny Pastuchowej [1999], związanych z Uniwersytetem Śląskim, seria podręczników „Hurra!” [Małolepsza, Szymkiewicz 2006] wydanych kilka lat temu przez szkołę językową Prolog (jest to seria wciąż wznawiana i wzbogacana o kolejne pomoce dydaktyczne), nieco nowsze podręczniki z serii „Polski, krok po kroku”, również opublikowane przez wydawnictwo związane z krakowską prywatną szkołą językową Glossa, oraz najnowsza w tym zbiorze pozycja z 2013 roku Polski jest Cool [Piotrowska-Rola, Porębska 2013], która powstała w Szkole Języka i Kultury Polskiej przy Katolickim Uniwersytecie Lubelskim. Wszystkie cztery tytuły pojawiają się najczęściej w sylabusach lektoratów języka polskiego na włoskich uniwersytetach jako główne (lecz niejedyne) podręczniki kursowe. Lektorzy cenią w nich m.in różnorodność ćwiczeń kształtujących kompetencję komunikacyjną i wszystkie sprawności językowe, przejrzystą kompozycję oraz bogactwo materiałów dodatkowych, a studenci: ,żywy” język, słownictwo codzienne, wiele odniesień do popkultury czy też bogatą szatę graficzną. Nie są to jednak podręczniki pozbawione wad. Niestety, czasami ich autorzy próbują odtworzyć w tekstach i dialogach preparowanych polszczyznę naturalną, wręcz potoczną (co prowadzi do mieszania stylów i rejestrów języka), zapominając przy tym, że „Włoch, który uczy się angielskiego, woli teksty napisane mową Oxfordu, a nie londyńskiego przedmieścia (to samo dotyczy każdego innego języka, a zwłaszcza polskiego, mającego pięćsetletnią tradycję kulturalnego rozwoju)" [Wilkoń 2007: 266]. Podręczniki tego typu wykorzystywane są powszechnie w pracy lektorskiej na uniwersytetach całego świata. Czy zważając zatem na ich popularność zarówno w Polsce, jak i poza granicami kraju, możemy traktować je jako podręczniki akademickie sensu stricto? I czy student uczelni amerykańskiej, włoskiej i rosyjskiej w równym stopniu przyswoi z nich znajomość języka polskiego?

O ile na pierwsze pytanie odpowiedź może być dyskusyjna (bowiem: jakie kryteria musiałby spełniać podręcznik akademicki? gdzie przebiega cezura?), o tyle trudno się zgodzić z tym, iż ten sam podręcznik może być z sukcesem stosowany w pracy akademickiej ze studentami-filologami o odmiennym języku wyjściowym. Szczególnie ze względu na metodologię pracy wpisaną już niejako w podręcznik, wyraźnie wskazującą na profilowanie pracy w kierunku metod bezpośrednich, monolingwalnych. Warto też zasygnalizować tu pytanie, czy wybór metody bezpośredniej (lub jej bardziej jaskrawego wariantu metody naturalnej) może prowadzić do zamierzonych rezultatów w grupie studentów - przyszłych filologów, językoznawców, tłumaczy? Pozostawiam tu miejsce do refleksji, jednak z pełnym przekonaniem mogę stwierdzić, iż istnieje znaczna różnica $\mathrm{w}$ pracy z podręcznikiem ukierunkowanym na określoną grupę etniczną i wspomnianym podręcznikiem ogólnym. Warto więc poddać 
rewizji podział podręczników i pomocy dydaktycznych zaproponowany przez autorki w swoistym przewodniku dla nauczycieli. Chodzi o $A B C$ metodyki nauczania języka polskiego jako obcego, w którym w jednej grupie, określonej jako ,podręczniki ogólne”, znajdują się obok wcześniej wspomnianej publikacji Dzień dobry pozycje przeznaczone dla konkretnej nacji (np. Czy Czechów jest trzech? Podręcznik języka polskiego dla Czechów [Posingerowa, Seretny 1992] lub Poola keel. Podręcznik języka polskiego dla Estończyków [Lemmi, Stefańczyk 2000]) [Lipińska, Seretny 2005: 309]. Pozostałe materiały edukacyjne zostały sklasyfikowane przez autorki jako pomoce do nauczania: wymowy polskiej, ortografii, słownictwa, gramatyki (a wśród nich: gramatyki pedagogiczne i zbiory ćwiczeń), rozumienia ze słuchu, mówienia, czytania, pisania oraz zbiory testów i dodatkowo słowniki (ogólne języka polskiego, specjalistyczne, słowniki specjalistyczne i ogólne dla cudzoziemców). Może warto byłoby zatem stworzyć osobną podkategorię podręczników ukierunkowanych na odbiorcę pod względem etnicznym. Tego typu systematyzacja nie tylko byłaby wskazana z uwagi na coraz większą na rynku wydawniczym liczbę publikacji sprofilowanych językowo, ale także stanowiłaby cenną wskazówkę dla lektorów pracujących ze studentami kierunków filologicznych za granicą.

W sylabusach i programach kursów języka polskiego na uczelniach włoskich wśród podręczników przeznaczonych dla studenta włoskojęzycznego najczęściej powtarzają się wciąż te same pozycje. Są to publikacje różnego rodzaju: kompendia gramatyczne ze zbiorem ćwiczeń (np. Grammatica teorico pratica della lingua polacca [Lewiński 2004], Z ziemi włoskiej do Polski. Manuale di grammatica polacca per italiani [Lipińska 2010]), podręczniki typu ogólnego kształtujące w różnych proporcjach wszystkie - bądź prawie wszystkie - sprawności językowe (np. Impariamo il polacco [Bartnicka 1994], Corso di lingua polacca [Marinelli, Stryjecka 2014]) lub też konkretne umiejętności (np. Esercizi fonetici ed ortografici nella lingua polacca [Pawlak 2006]). Łączy je jedna cecha - język medium, czyli język włoski. Wśród sprofilowanych językowo podręczników należy dokonać bardzo istotnego rozróżnienia - mianowicie: czy są one bezpośrednim tłumaczeniem z języka polskiego na włoski (czyli bez elementów porównawczych), czy też jest to tłumaczenie opatrzone komentarzem dostosowanym do potrzeb studentów włoskojęzycznych, albo - czy jest to publikacja od podstaw pisana z myślą o Włochach. O ile pierwszy przypadek nie wnosi wiele poza tłumaczeniem tekstu, o tyle drugi i trzeci wprowadzają metarefleksję nad językiem rodzimym, poszerzając tym samym językoznawcze horyzonty myślowe studentów. Jest to szczególnie cenne na studiach filologicznych, gdyż pozwala na naukę poprzez komentarz kontrastywny. Rolę takiego nauczania podkreśla Aneta Banach [2013: 173]: 
[...] interferencja międzyjęzykowa nie jest jedynym źródłem i wyjaśnieniem wszystkich błędów popełnianych w języku obcym, ale wydaje się, że warto uwzględniać wyniki analiz kontrastywnych w praktyce dydaktycznej, zwłaszcza w pracy z grupami jednorodnymi językowo.

Ważne jest przy tym, by lektor zorientował się, czy dany błąd popełniony przez studenta jest wynikiem interferencji czy też zwykłego przejęzyczenia. I tutaj mogą przyjść z pomocą właśnie podręczniki kierowane do studentów włoskojęzycznych [Banach 2013: 174].

Do grupy podręczników, które mają swój polski pierwowzór, lecz dostosowane zostały do włoskojęzycznego studenta, można zaliczyć publikację Impariamio il polacco wydaną i wielokrotnie wznawianą przez Wiedzę Powszechną. Jest to tłumaczenie pierwotnej wersji Uczymy się polskiego napisanej w języku polskim i przetłumaczonej na różne języki europejskie. Innym przykładem może być podręcznik do nauki gramatyki Ewy Lipińskiej [2010] Z ziemi włoskiej do Polski, bazujący na treściach polskiego podręcznika Z polskim na ty tej samej autorki. Obie publikacje włoskojęzyczne w swych tłumaczeniach zostały opatrzone dodatkowymi przykładami bądź komentarzami ułatwiającymi zrozumienie struktur gramatycznych poprzez porównanie ich do języka włoskiego (np. w części fonetycznej podano odpowiedniki głosek włoskich). Podręcznikiem stworzonym od podstaw z myślą o studentach włoskojęzycznych jest najnowszy i - w odróżnieniu od poprzednich - wydany we Włoszech w 2014 roku Corso di lingua polacca autorstwa Luigiego Marinellego i Agnieszki Stryjeckiej [2014], związanych z Uniwersytetem La Sapienza w Rzymie. Publikacja ta - choć ma pewne cechy podręcznika ogólnego skoncentrowana jest głównie na kształtowaniu poprawności gramatycznej, obrazowanej miejscami przykładami z gramatyki kontrastywnej. I jest to bez wątpienia książka rangi podręcznika akademickiego do nauczania treści gramatycznych. Obok wspomnianych już podręczników o charakterze ogólnym i profilowanym, we włoskich sylabusach wskazane są również kompendia gramatyczne, wśród których można zastosować dwojakie kryteria podziału: a) ze względu na język medium, czyli podręczniki napisane w języku włoskim (np. Grammatica essenziale della lingua polacca per stranieri [Foland-Kugler 2006] i w języku docelowym - polskim (np. Gramatyka języka polskiego. Podręcznik dla cudzoziemców [Bartnicka, Satkiewicz 2010]), oraz b) podział na gramatyki pedagogiczne i ogólne opisowe.

Z powyższych rozważań wynika, że na zajęciach z języka polskiego jako obcego w Italii korzysta się najczęściej z trzech rodzajów publikacji: podręcznika ogólnego, podręcznika sprofilowanego i kompendium gramatycznego 
(w języku polskim lub/i włoskim). Do tej listy należy dopisać równie często wykorzystywane zbiory ćwiczeń oraz słowniki. Tym samym lista pozycji w bibliografii rozrasta się, często nawet do 10 i więcej tytułów. Którą z tych publikacji można uznać zatem za podręcznik kursowy? Ze względów organizacyjnych najlepiej byłoby wskazać jedną, dwie pozycje, jednak - co wynika z powyższych analiz - wydaje się to niemożliwe. Podręcznik ogólny jest niewystarczający na zajęcia o profilu filologicznym, powinien zostać zatem dopełniony publikacjami o charakterze naukowym. Natomiast podręczniki skupione na poprawności gramatycznej często zaniedbują kształtowanie pozostałych sprawności językowych. Hipotetyczny podręcznik w postaci eklektycznej, łączący cechy każdej z wymienionych wcześniej pozycji, również wydaje się przedsięwzięciem utopijnym, choćby ze względu na niewyobrażalną objętość publikacji (a pominęliśmy przecież zupełnie kształtowanie kompetencji kulturowej, która również stanowi duży blok zagadnień na zajęciach lektoratu). Dodatkowym utrudnieniem jest fakt, że większość materiałów dydaktycznych (szczególnie podręczników ogólnych) tworzona jest tylko na najniższych poziomach biegłości językowej (A1, A2). Jak zatem radzą sobie w tej sytuacji lektorzy? We wspomnianych badaniach ankietowych autorka podsumowuje, iż lektorzy włoscy przyznają jednogłośnie, że

podczas zajęć korzystają z wielu, bardzo różnorodnych dodatkowych materiałów dydaktycznych, takich jak artykuły prasowe, autentyczne nagrania radiowe i telewizyjne, fragmenty polskiej prozy i poezji oraz wydawnictwa książkowe i materiały audiowizualne przygotowane w głównych polskich ośrodkach glottodydaktycznych - krakowskim, śląskim, warszawskim i wrocławskim. Z racji braku odpowiednich podręczników rozwijających wszystkie sprawności i podsystemy języka na poziomie zaawansowanym, prawidłowe nauczanie polszczyzny na tym poziomie uzależnione jest od samodzielnej pracy i inwencji lektora. [Marzec 2009: 61]

Czy zatem skazani jesteśmy na korzystanie z wielu pozycji, co wydaje się złotym środkiem, jednak negatywnie wpływa na jakość pracy, gdyż w praktyce oznacza dezorganizację, nieczytelne fotokopie, tworzenie eklektycznych skryptów itp.?

Bogactwo pomocy dydaktycznych jest niewątpliwie nieocenioną zaletą, jednak mądre czerpanie z tego źródła i umiejętny dobór pozycji wymaga sporych zdolności. Dodatkowo wybór ten należy poddawać systematycznej rewizji, gdyż treści poszczególnych publikacji z czasem się dezaktualizują lub nie przystają do oczekiwań i możliwości grupy. Dlatego indywidualna selekcja dostępnych materiałów, a następnie ich adaptacja do potrzeb nauczania akade- 
mickiego w konkretnym środowisku wydaje się naturalnym etapem budowania programu nauczania w każdym ośrodku uniwersyteckim i trudno oczekiwać, że ten proces zastąpi jakikolwiek podręcznik kursowy. Alternatywnego rozwiązania i pewnego ułatwienia można natomiast poszukiwać na gruncie nowych technologii i innowacyjnych rozwiązań z dziedziny IT. Jedną z koncepcji, która doczekała się realizacji w środowisku włoskiej polonistyki, było stworzenie interaktywnej platformy e-learningowej do nauczania języka polskiego jako obcego na poziomie wstępnym (A1) w ramach międzynarodowego projektu E-LOCAL. Idea narodziła się w 2010 roku z inicjatywy kierownika katedry polonistyki Uniwersytetu Bolońskiego i jest wciąż kontynuowana, a jej rezultaty $\mathrm{z}$ sukcesami wykorzystywane są $\mathrm{w}$ dydaktyce języka polskiego jako obcego na uniwersytetach włoskich i nie tylko. Projekt E-LOCAL składał się z kilku etapów i obecnie jest w fazie przygotowywania aplikacji do nauczania języka polskiego jako obcego dla systemów Android. W niniejszej publikacji skoncentruję się jednak tylko na rozważaniach dotyczących samej platformy e-learnigowej E-LOCAL, która z powodzeniem może przejąć rolę przewodniego materiału dydaktycznego. Celowo nie używam tu terminu ,podręcznik kursowy", by odróżnić platformę od interaktywnych i internetowych podręczników (tzw. e-podręczników) oraz podkreślić jej eklektyczny wymiar. Platforma może bowiem zarówno stanowić bazę, którą lektor dowolnie modyfikuje, dodając wybrane przez siebie kolejne materiały dydaktyczne, jak i posłużyć jako narzędzie komunikacji ze studentami.

Kurs E-LOCAL składa się z dziesięciu jednostek, podzielonych na pięć części: e-Story, e-Grammar, e-Culture, e-Life oraz e-Language exercises. Już w pierwszej z nich student poznaje głównych bohaterów kursu - Annę i Alexaktórzy próbują opanować język polski przed rozpoczęciem studiów w Poznaniu w ramach programu wymiany Erasmus. Tak skonstruowana historia, która prowadzi studentów przez różne perypetie życia codziennego Anny i Alexa, a kończy się na rozpoczęciu roku akademickiego w Polsce, pomaga utożsamiać się kursantom z sytuacją głównych bohaterów. Tym samym w kurs E-LOCAL wpisany jest konkretny użytkownik - student uczący się języka poza Polską. Językiem medium platformy jest angielski, w którym podane są objaśnienia gramatyczne, słowniczek i polecenia, jednak w tym miejscu lektor ma pewne pole manewru, gdyż do dowolnej lekcji może dodać niezbędne informacje w języku wyjściowym. Interaktywne, różnorodne ćwiczenia pozwalają na kształtowanie wszystkich sprawności językowych. Poza tym platforma została wzbogacona o różnego rodzaj nagrania i teksty autentyczne. Bardzo interesującą częścią jest blok obejmujący zagadnienia kulturowe (e-culture), począwszy od podstawowej wiedzy o Polsce (Polska w pigułce), jak położe- 
nie geograficzne itp., przez informacje historycznoliterackie, po wydarzenia i postaci z kultury współczesnej oraz popkultury. Osobny blok zagadnień dotyczy obyczajowości i życia codziennego Polaków (e-life).

Obie sekcje mogą być na bieżąco rozbudowywane i uaktualniane, bowiem osadzenie kursu na platformie Moodle daje lektorowi szeroki wybór narzędzi pozwalających ingerować w strukturę kursu i sukcesywnie stawać się niejako jego współautorem: dodawać i usuwać materiały do poszczególnych lekcji, tworzyć nowe ćwiczenia, testy, quizy i inne prace kontrolne. Umożliwia to ciągłą rewizję i aktualizację treści w odróżnieniu od tradycyjnej formy podręcznika kursowego. Dodatkowo platforma Moodle oferuje bogactwo narzędzi komunikacyjnych, takich jak czat lub forum, które pozwalają na dialog ze studentem również poza kursem tradycyjnym, a interaktywny kalendarz przypomina o przewidzianych przez nauczyciela spotkaniach na czacie lub interesujących wydarzeniach pozauniwersyteckich. Lektor ma również do dyspozycji wiele narzędzi kontrolnych: może śledzić postępy studenta w wykonywaniu ćwiczeń, zdobytą przez niego punktację, a nawet czas, który poświęcił na naukę danego zagadnienia z wykorzystaniem platformy. Możliwości moderatora są bardzo szerokie, ponieważ platforma nie ma limitów objętościowych, co oznacza, że można wgrać na nią wiele treści i udostępniać je całym grupom studentów bądź studentom indywidualnym w zależności od wizji danego kursu. Istnieje również możliwość włączenia studentów w budowanie kursu języka poprzez udostępnienie im opcji dodawania treści za pomocą narzędzi forum (idealnie sprawdza się tu technika projektu, np. studenci mogą sami tworzyć sekcje o aktualnościach społeczno-kulturalnych w Polsce na bazie internetowych źródeł włoskojęzycznych, dodawać artykuły, zdjęcia, dyskutować itp.; podobnie mogą powstać sekcje dotyczące muzyki polskiej bądź filmu). Na tej samej zasadzie nauczyciel może tworzyć dodatkowe, specjalistyczne działy nauczania, np. dotyczące frazeologii, języka technicznego, przekładu, historii języka itd. - wszystko zależy od profilu kursu oraz wizji i kreatywności lektora.

To bogactwo narzędzi interaktywnych przekłada się na szerokie spektrum możliwości metodycznych. Pozwala zarówno na tradycyjne zajęcia klasowe z wykorzystaniem platformy na lekcji, jak i na naukę indywidualną studenta (e-learning), realizując przy tym postulat możliwości fakultatywnego uczestnictwa w zajęciach, będący prawem (a raczej przywilejem) studentów włoskich. Istnieje również trzeci wariant $\mathrm{z}$ wykorzystaniem metody zintegrowanej (blended learning), będącej swoistą kombinacją poprzednich metod. Oznacza ona pracę grupową w klasie i indywidualną studenta w domu oraz kontakt z nauczycielem na kształt opieki mentorskiej poprzez narzędzia komunikacji platformy (np. czat, fora, mailing). W ten sposób można też moderować pracę 
indywidualną ze studentem, co jest szczególnie istotne przy pracy z uczniem słabszym (np. w ramach spotkań wyrównujących) oraz z uczniem zdolnym (np. poprzez dodawanie fakultatywnych ćwiczeń i tekstów). Ostatnim argumentem przemawiającym za tego typu edukacją w zagranicznych placówkach jest fakt, iż forma pracy z platformą może posłużyć również jako tymczasowe rozwiązanie problemów (choć nie lekarstwo na nie) natury administracyjnej (ograniczeń godzinowych, kadrowych czy lokalowych), które często wskazywane są jako czynnik kryzysogenny na studiach polonistycznych poza granicami kraju.

Mimo wielu korzyści, jakie niewątpliwie dają kursy on-line, należy liczyć się z pewnymi trudnościami, którym lektor będzie musiał sprostać. Należy do nich m.in. opanowanie narzędzi Moodle, które choć często wydają się intuicyjne, to jednak wymagają poświęcenia dużej ilości czasu na stworzenie dodatkowych materiałów lub testów. W ostatecznym rozrachunku jest to jednak czas zaoszczędzony, gdyż materiał raz wgrany pozwala na jego wielokrotne wykorzystywanie. Największą trudnością stawianą przed lektorami w pracy z platformą - z czym zgadza się wielu nauczycieli praktyków [Pabiańczyk 2013: 384] - jest utrzymywanie stałej motywacji uczniów i wspieranie ich w narzuceniu sobie samodyscypliny niezbędnej w pracy autodydaktycznej. Sprawienie, by regularny kontakt z platformą wszedł w nawyk dnia codziennego kursantów, jest nie lada wyzwaniem. Do listy trudności należy też dodać czysto techniczne przeszkody, np. brak sali multimedialnej lub niewystarczającą liczbę komputerów.

Podsumowując przedstawione w niniejszym artykule rozważania, można stwierdzić, że choć od początku nowego tysiąclecia wykorzystywanie nowatorskich rozwiązań z dziedziny IT w edukacji staje się coraz powszechniejsze $\mathrm{i}$ bardziej oczywiste, to nowe media dopiero raczkują w kształceniu akademickim. Czymże bowiem jest niespełna dwudziestoletnie doświadczenie wobec kilkuwiekowej tradycji pracy z podręcznikiem drukowanym (bądź rękopisem). Coraz częściej słychać też głosy nawołujące do powrotu do sprawdzonych koncepcji. Nie uważam, że innowacyjność jest synonimem poprawy jakości kształcenia, gdyż nawet najbardziej zaawansowane technologicznie rozwiązania nie zastąpią dobrze przygotowanego merytorycznie nauczyciela i nie wyręczą go w wypracowaniu najlepszej metody nauczania oraz doborze materiałów dydaktycznych czy wyborze podręcznika kursowego. Mogą jednak ten proces znacznie ułatwić, a także usprawnić komunikację nauczyciel - uczeń. Korzystanie z nowoczesnych rozwiązań, do których należy platforma e-learningowa, wymaga wypracowania optymalnej koncepcji pracy i poddania jej rezultatów naukowej weryfikacji, co z perspektywy lektora pracującego poza granicami kraju - mam nadzieję - niebawem nastąpi. 


\section{Bibliografia}

\section{Źródta}

Bartnicka Barbara (1994), Impariamo il polacco, Wiedza Powszechna, Warszawa.

Bartnicka Barbara, Satkiewicz Halina (2010), Gramatyka języka polskiego. Podręcznik dla cudzoziemców, Wiedza Powszechna, Warszawa.

Dawidek Sylwia, Stelmach Anna, Stempek Iwona, Szymkiewicz Aneta (2010), Polski, krok po kroku 1, Glossa, Kraków.

Erin Lemmi, Stefańczyk Wiesław (2000), Poola keel. Podręcznik języka polskiego dla Estończyków, Wiedza Powszechna, Warszawa.

Foland-Kugler Magdalena (2006), Grammatica essenziale della lingua polacca per stranieri, Exlibris, Warszawa.

Janowska Aleksandra, Pastuchowa Magdalena (1999), Dzień dobry. Podręcznik do nauki języka polskiego dla początkujących, Śląsk, Katowice.

Lewiński Piotr (2004), Grammatica teorico pratica della lingua polacca, Universita degli Studi di Napoli, Neapol.

Lipińska Ewa (2010), Z ziemi włoskiej do Polski. Manuale di grammatica polacca per italiani, Universitas, Kraków.

Małolepsza Małgorzata, Aneta Szymkiewicz (2006), Hurra! Po polsku 1, Prolog, Kraków.

Marinelli Luigi, Stryjecka Agnieszka (2014), Corso di lingua polacca, Hoepli, Mediolan.

Pawlak Dorota (2006), Esercizi fonetici ed ortografici nella lingua polacca, Libreria Editrice Cafoscarina, Wenecja.

Piotrowska-Rola Ewa, Porębska Marzena (2013), Polski jest Cool, Episteme, Lublin.

Posingerowa Katerina, Seretny Anna (1992), Czy Czechow jest trzech? Podręcznik języka polskiego dla Czechów, Biblioteka Pomocy Dydaktycznych, Kraków.

\section{Literatura}

Banach Małgorzata (2013), Czy studenci włoscy ucza się z pasja języka polskiego? O specyfice nauczania języka obcego studentów włoskojęzycznych - wybrane problemy, w: Edukacja Międzykulturowa. Forum Glottodydaktyczne. Materiaty z Konferencji Naukowej, red. Anna Rabczuk, Pollonicum, Warszawa, s. 167-176.

Lektoraty języka polskiego dla obcokrajowców we Włoszech (2016), www.rzym.msz. gov.pl/pl/informacje_konsularne/nauka_polskiego_we_wloszech/polski_we_wloszech/, [dostęp: 15 stycznia 2016].

Lipińska Ewa, Seretny Anna (2005), ABC metodyki nauczania języka polskiego jako obcego, Universitas, Kraków. 
Marzec Urszula (2009), Obraz polonistyki włoskiej w świetle badań ankietowych, Universitas, Kraków.

Pabiańczyk Agnieszka (2013), Blended learning, czyli nauczanie mieszane wykorzystywane w nauczaniu języka polskiego jako obcego, w: Edukacja Międzykulturowa. Forum Glottodydaktyczne. Materiaty z Konferencji Naukowej, red. Anna Rabczuk, Pollonicum, Warszawa, s. 382-391.

Seretny Anna (2006), Metody nauczania języków obcych a nauczanie języka polskiego - zarys, w: Z zagadnień dydaktyki języka polskiego jako obcego, red. Ewa Lipińska, Anna Seretny, Universitas, Kraków, s. 131-154.

Wilkoń Teresa (2007), Podstawowe trudności w nauczaniu języka polskiego jako obcego na poziomie początkujacym we Włoszech, „Postscriptum”, t. 1 (53), s. 259 269.

Małgorzata Jakobsze

The choice of coursebook for academic language classes of Polish as a foreign language (on the example of Polish studies in Italy)

The primary aim of the article was a reflection on the choice of a coursebook for the Polish language course at Italian universities. The first part of this paper describes the specifics of Polish studies in Italy and focuses on conditions influencing the choice, such as: the profile of the student, type of course and the educational context. The second part presents classifications of manuals used for Polish language courses in Italy. This classifications are accompanied by a list of criteria which help to select some particular groups of manuals.

The secondary aim of the article, which is presented in the last part, was to introduces an e-learning platform E-LOCAL supporting a Polish language teaching as an alternative, modern and customizable coursebook.

KeYwords: glottodidactics; coursebook; e-learning; blended learning; Polish as a foreign language.

mgr Małgorzata Jakobsze - lektorka na Uniwersytecie Bolońskim, doktorantka na Wydziale Filologii Polskiej i Klasycznej Uniwersytetu im. Adama Mickiewicza w Poznaniu; zainteresowania naukowe: metodyka nauczania JPJO z wykorzystaniem rozwiązań z dziedziny IT, tematyka dwujęzyczności u dzieci i młodzieży. 
